SocioEconomic Challenges, Volume 4, Issue 4, 2020

ISSN (print) - 2520-6621, ISSN (online) - 2520-6214

\title{
The Impact of China-US Trade Conflict on Korean Economy
}

https://doi.org/10.21272/sec.4(4).18-28.2020.

\author{
He Shuquan, ORCID: https://orcid.org/0000-0002-4159-4365 \\ PhD, Professor, Department of Economics, School of Economics, Shanghai University, China \\ Sora Ju \\ Master Student, School of Economics, Shanghai University, China
}

\begin{abstract}
This paper concentrated on how US-China Trade conflicts would have impacts on Korean economy. Making the best use of WIOTs (World Input Output tables), this research focused on value added contents in trade instead of traditional trade statistics in the light of double-counting problem. Thus, the paper set two feasible bad-case scenarios: when China and US's GDP fall and when China and US's exports fall.

Making a comparison of the results from the two models, the ripple effects that Korea would suffer from are bigger in China's case. Even though it is under the same condition where China and US's GDP identically fall by $1 \%$, China's case would bring about stronger impacts on Korea. In a nutshell, the outcome illustrates that the extent of the damage that Korea would undergo is always larger in China's bad-case scenarios compared to US's bad-case scenarios which reveals that Korea is more associated with China than US in global value chains. The findings of the analysis are arranged and diagrammed in a table as follows.
\end{abstract}

Keywords: China, US, China-US Trade War, Korean Economy, WIOTs.

JEL Classification: F12, F17, F21.

This work is licensed under a Creative Commons Attribution 4.0 International License.

Cite as: He Shuquan, Sora Ju. (2020). The Impact of China-US Trade Conflict on Korean Economy. SocioEconomic Challenges, 4(4), 18-28. https://doi.org/10.21272/sec.4(4).18-28.2020.

(C) The Authors, 2020. This article is published with open access at Sumy State University.

\section{Introduction}

The biggest hot issue around the world lately is trade conflicts between China and US. Since US imposed the first China-specific tariffs on Chinese imports in 2017, China confronted the preemptive strike with a chain of retaliatory tariff actions and the all-out trade war between China and US has unfolded. At present, three rounds of bilateral tariff plans are in effect and considering roll-out of the upcoming tariff plan delayed at the moment, they target a substantial amount of mutual imported goods. It seems that these trade disputes would continue to stagnate as they have extended the scope of the disputes from tariff to non-tariff areas. As China and US are the world largest economies, biggest markets and industries, it is attracting the world's keen attention. Not confined to their own matters, it has brought the world to anxiety and distress. It is obvious that it would affect adverse impacts on countries in a range of global value chains. South Korea, one of those countries highly engaged with China and US respectively, is likely to be damaged by China and US's protectionism. Thus, this study hereafter will observe China-US trade war and the feasible effects on Korean economy and more importantly, see trade in value added approach instead of the standard trade in gross term.

In order to quantify how China and US's protectionism would have a negative impacts on Korean economy, this paper assumes China and US's bad-case scenarios on the preferential basis where China and US's low growth rate and poor exports. Based on those assumptions, it would like to detect how much of effect Korea would have on GDP and exports. For data, it aims to fully tap into WIOTs 2014 provided by the Joint Research Centre of 
European Commission. Basically, the paper utilizes TiVA analysis in the first model and a methodology of decomposition of gross exports in the second model. The findings show that there are significant impacts on Korean economy. Under the two models where China and US's GDP and exports are expected to decrease, the extent of damage to Korea is always larger in China's scenarios compared to US's scenarios.

\section{Data}

This paper fundamentally underlies a good use of WIOD. Pursuant to the theme of this study, it mainly focuses on three countries (China, US and Korea) and counts other countries as rest of the world for computational convenience. Leaving the existing classification of the sectors intact, the paper utilizes the restructure of three countries where input output tables are recompiled from 44-country 56-sector to 4-country (China, US, Korea, Rest of the World) 56-sector or 3-country (China, US, Rest of the World) 56-sector in some cases.

\section{Models}

This paper aims to set two different models in which China and US would face bad-case scenarios from their protectionism-friendly policies. The first model assumes China and US's slow economic growth in terms of GDP and it would like to observe its feasible impacts on Korea's GDP. For measurement of their expected decrease in GDP, it follows the precedent studies mentioned earlier in Table 6. In this model, the study intends to see GDP by means of TiVA analysis.

The second model assumes China and US's exports reduction. In the first place, it performs elasticity analysis in order to compute their expected decreased exports and identifies Korea's forward and backward linkages in China and US bilateral exports through decomposition of gross exports. Forward linkage represents Korea's association on production side and backward linkage stands for Korea's association on final demand side. Thus, the study focuses on Korea's exports to both countries in forward linkage aspect and Korea's GDP in backward linkage aspect. Thus, the paper expects that Korea would have adverse impacts on GDP and exports in these two models.

Table 1. Research Models

\begin{tabular}{|l|l|l|}
\hline \multirow{3}{*}{ Model (1) } & (1)-1 When China's GDP falls & How much of effect would it have on Korea's GDP? \\
\cline { 2 - 3 } & (1)-2 When US's GDP falls & How much of effect would it have on Korea's GDP? \\
\hline \multirow{4}{*}{ Model (2) } & \multirow{3}{*}{\begin{tabular}{l} 
(2)-1When China's exports to US fall \\
\cline { 2 - 3 }
\end{tabular}} & $\begin{array}{l}\text { How much of effect would it have on Korea's exports? } \\
\text { forward linkage perspective }\end{array}$ \\
\cline { 2 - 3 } & \multirow{2}{*}{$\begin{array}{l}\text { (2)-2 When US's exports to China fall } \\
\text { backward linkage perspective }\end{array}$} \\
\hline
\end{tabular}

Source: the author.

\section{Results}

1. Reinterpretation of Trade in Value AddedApproach

Table 2. Comparison of Trade in Gross Value and Trade in Value Added (2014, billions of dollars)

\begin{tabular}{|l|c|c|c|c|c|c|}
\hline \multirow{2}{*}{} & \multicolumn{3}{|c|}{ Trade in gross value } & \multicolumn{3}{c|}{ Trade in value added } \\
\cline { 2 - 7 } & Trade balance & Exports & Imports & Net Value & Value added exports & $\begin{array}{c}\text { Value added } \\
\text { imports }\end{array}$ \\
\hline China & 582.7 & $2,425.5$ & $1,842.8$ & 598.8 & $1,932.8$ & $1,334.0$ \\
\hline US & -480.6 & $1,927.1$ & $2,407.7$ & -416.7 & $1,604.2$ & $2,020.9$ \\
\hline Korea & 135.2 & 697.9 & 562.7 & 111.9 & 416.7 & 304.8 \\
\hline
\end{tabular}

Source: calculated by the author based on WIOT 2014 database. 
In 2014, when it comes to comparison of trade in gross value and trade in value added, China's export is US $\$ 2,425.5$ billion and its import is US\$ $1,842.8$ billion so its trade balance amounts to US\$ 582.7 billion. On the other hand, calculating trade in TiVA method shows that China's export is US\$ $1,932.8$ billion and its import is 1,334 billion and thus, net value accounts for US\$ 598.8bilion and this figure is rather bigger in comparison with gross term. In terms of US's trade with the world, its trade deficit reaches to US\$ 480.6 billion but it is US\$ 416.7 billion in TiVA term. Likewise, Korea's trade balance is US\$ 135.2billion in gross value but it is US\$111.9billion in value added term. That is, the standard trade statistics has overvalued figures in gross value term due to double counting of intermediate output so the figures are smaller than in TiVA.

Table 3. China's Trade with US in Value Added (2014, billions of dollars)

\begin{tabular}{|l|c|c|c|}
\hline & Net value & Value added exports & Value added imports \\
\hline US & 195.5 & 317.3 & 121.8 \\
\hline
\end{tabular}

Source: calculated by the author based on WIOD 2014.

Table 4. Korea's Trade with China and US in Value Added (2014, billions of dollars)

\begin{tabular}{|c|c|c|c|}
\hline & Net value & Value added exports & Value added imports \\
\hline China & 29.5 & 85.0 & 55.5 \\
\hline US & 28.0 & 61.0 & 33.0 \\
\hline
\end{tabular}

Source: calculated by the author based on WIOD 2014.

In view of TiVA approach, when it comes to China's trade with US, value added exports amount to US\$ 317.3 billion and value added imports amount to US\$121.8billion. Thus, net value (trade balance in value added) is US\$ 195.5billion and US's trade with China, vice versa. Looking at Korea's trade with G2 in value added, with respect to Korea's trade with China, its value added exports is US\$ 85billion and its value added imports is US\$ 55.5billion, whereupon the net value becomes US\$29.5billion. In terms of Korea's trade with US, meanwhile, its value added exports is US\$ 61billion and its value added imports is US\$33billion. Thus, the net value is US\$ 28 billion. From net value's point, there is no huge difference in contrast with gross value trade.

\section{$2 \quad$ When China and US's GDP Fall}

Table 5. GDP by Countries in Value Added Approach (2014, billions of dollars)

\begin{tabular}{|c|c|c|c|c|c|c|c|c|c|c|c|c|}
\hline \multirow{3}{*}{$\begin{array}{l}\text { Country } \\
\text { China }\end{array}$} & \multirow{3}{*}{$\begin{array}{c}\text { GDP } \\
(\mathbf{1})+(\mathbf{2})\end{array}$} & \multirow{2}{*}{\multicolumn{2}{|c|}{$\begin{array}{c}\text { Domestic demand } \\
\text { (1) }\end{array}$}} & \multicolumn{9}{|c|}{ Foreign demand (value added exports) (2) } \\
\hline & & & & \multirow{2}{*}{$\begin{array}{c}\text { Total } \\
1,932.8 \\
\end{array}$} & \multicolumn{2}{|c|}{ China } & \multicolumn{2}{|c|}{ US } & \multicolumn{2}{|c|}{ Korea } & \multicolumn{2}{|c|}{ RoW } \\
\hline & & $8,351.2$ & $81.2 \%$ & & - & - & 317.3 & $3.1 \%$ & 55.5 & $0.5 \%$ & $1,559.9$ & $15.2 \%$ \\
\hline US & $17,348.1$ & $15,743.8$ & $90.8 \%$ & $1,604.2$ & 121.8 & $0.7 \%$ & - & - & 33.0 & $0.2 \%$ & $1,449.5$ & $8.4 \%$ \\
\hline Korea & $1,287.1$ & 870.3 & $67.6 \%$ & 416.7 & 85.0 & $6.6 \%$ & 61.0 & $4.7 \%$ & - & - & 270.7 & $21.0 \%$ \\
\hline RoW & $44,887.8$ & $41,901.7$ & $93.3 \%$ & $2,986.1$ & $1,127.2$ & $2.5 \%$ & $1,642.6$ & $3.7 \%$ & 216.3 & $0.5 \%$ & - & - \\
\hline
\end{tabular}

Source: calculated by the author utilizing WIOD 2014.

Note 1) Foreign demand, also known as value added exports is a given country's value added created in foreign demand.

Note 2) RoW stands for rest of the world.

The table describes GDP using value added approach. Redefining the concept of it in value added aspect, GDP is value added created by countries (home country plus foreign countries)' final demand. Out of GDP, China's domestic demand accounts for $81.2 \%$ and the rest, $19.8 \%$ of value added is created from foreign countries' final demand. In other words, foreign demand can be represented as GDP's foreign dependence. US\$ 317.3billion of US's final demand contributes to value added creation in China, which is equal to $3.1 \%$ of China's GDP. US\$ 55.5 billion of Korea's final demand contributes to value added creation in China, which is equal to $0.5 \%$ of all. In the case of US, its GDP's domestic reliance is the highest among three countries which accounts for $90.8 \%$. US's GDP dependence on China is $0.7 \%$ of all and the one on Korea is $0.2 \%$ of all. Korea can be characterized as a country that has relatively low domestic dependence and high foreign dependence. Its value added created 
from domestic demand is $67.6 \%$, whereas its value added created from foreign demand is $33.4 \%$. Among them, $6.6 \%$ of Korea's GDP comes from China's final demand 4.7\% of Korea's GDP comes from US's final demand.

Table 6. How China and US's GDP would affect Korea's GDP (2014)

\begin{tabular}{|c|c|c|}
\hline & Korea's GDP growth & Value \\
\hline When China's GDP fall by 1\% & $-0.066 \%$ & - US\$ $850.2 \mathrm{million}$ \\
\hline When US's GDP fall by 0.3\% & $-0.014 \%$ & - US\$ $182.9 \mathrm{million}$ \\
\hline Total effect & $-0.080 \%$ & - US\$ $1,033.1 \mathrm{million}$ \\
\hline
\end{tabular}

Source: calculated by the author based on WIOD 2014 database.

Note 1) Escalated protectionism would push prices up, which might induce consumers to contract spending and a country's final demand would fall accordingly. On the ground of that, the paper set an assumption that China's GDP falls by $1 \%$, and US's GDP falls by $0.3 \%$ respectively. These figures are from Table 6's precedent studies.

G2's full-blown trade frictions would affect consumer's spending and their weakened purchasing power would potentially exert a harmful impact on those countries' GDP. In a scenario that China's final demand decreases by $1 \%$, the consequential outcome Korea would face is US\$ 850.2 million of GDP reduction, which would lead to $0.066 \%$ declined GDP growth in comparison with no GDP decline scenario baseline. Given the case that US's final demand fall by $0.3 \%$, the expected impact on Korea's GDP is equivalent to US\$ 182.9 million of reduction, i.e., GDP down by $0.014 \%$ relative to no scenario case. Hence, in the case of total impact that China's final demand decreases by $1 \%$ and US's final demand decreases by $0.3 \%$ simultaneously, it would definitely have an adverse effect on Korea's GDP amounting to approximately US\$ 1billion reduction. Thus, Korea's GDP would decline by $0.08 \%$ in consequence. Its detailed impacts on Korea's by-industry GDP is indicated as follows.

Table 7. The Effects of China and US's GDP decline on Korea's By-industry GDP (2014, \%, millions of dollars)

\begin{tabular}{|c|l|c|c|c|c|c|c|}
\hline \multicolumn{2}{|l|}{} & \multicolumn{2}{|c|}{$\begin{array}{c}\text { When China's GDP fall } \\
\text { by } \mathbf{1 \%}\end{array}$} & \multicolumn{2}{c|}{$\begin{array}{c}\text { When US's GDP fall by } \\
\mathbf{0 . 3} \%\end{array}$} & \multicolumn{2}{c|}{$\begin{array}{c}\text { G2 } \\
\text { Total effect }\end{array}$} \\
\hline Korea's GDP decrease by & Rate & Value & Rate & Value & Rate & Value \\
\hline Sector & Total & 0.06605 & 850.177 & 0.01421 & 182.933 & 0.08026 & 1033.110 \\
\hline 1 & Crop and animal production & 0.00048 & 6.237 & 0.00009 & 1.202 & 0.00057 & 7.439 \\
\hline 2 & Forestry and logging & 0.00005 & 0.612 & 0.00001 & 0.131 & 0.00006 & 0.743 \\
\hline 3 & Fishing and aquaculture & 0.00005 & 0.598 & 0.00001 & 0.171 & 0.00006 & 0.769 \\
\hline 4 & Mining and quarrying & 0.00023 & 2.992 & 0.00005 & 0.649 & 0.00028 & 3.641 \\
\hline 5 & Food and beverages & 0.00039 & 5.077 & 0.00007 & 0.903 & 0.00046 & 5.980 \\
\hline 6 & Textiles and apparel & 0.00160 & 20.563 & 0.00041 & 5.284 & 0.00201 & 25.847 \\
\hline 7 & Wood & 0.00009 & 1.192 & 0.00002 & 0.232 & 0.00011 & 1.424 \\
\hline 8 & Paper & 0.00038 & 4.922 & 0.00012 & 1.553 & 0.0005 & 6.475 \\
\hline 9 & Printing and recorded media & 0.00013 & 1.729 & 0.00003 & 0.323 & 0.00016 & 2.052 \\
\hline 10 & Coke and refined petroleum & 0.00084 & 10.810 & 0.00018 & 2.305 & 0.00102 & 13.115 \\
\hline 11 & Chemicals & $\mathbf{0 . 0 0 6 4 3}$ & $\mathbf{8 2 . 8 2 2}$ & $\mathbf{0 . 0 0 1 0 3}$ & $\mathbf{1 3 . 2 1 2}$ & $\mathbf{0 . 0 0 7 4 6}$ & $\mathbf{9 6 . 0 3 4}$ \\
\hline 12 & Pharmaceutical products & 0.00017 & 2.252 & 0.00003 & 0.344 & 0.0002 & 2.596 \\
\hline 13 & Rubber and Plastic & 0.00071 & 9.133 & 0.00018 & 2.288 & 0.00089 & 11.421 \\
\hline 14 & Non-metallic mineral & 0.00046 & 5.966 & 0.00007 & 0.852 & 0.00053 & 6.818 \\
\hline 15 & Basic metals & 0.00251 & 32.336 & 0.00064 & 8.289 & 0.00315 & 40.625 \\
\hline 16 & Fabricated metal products & 0.00200 & 25.784 & 0.00057 & 7.293 & 0.00257 & 33.077 \\
\hline 17 & Computer and electronic & $\mathbf{0 . 0 1 7 5 0}$ & $\mathbf{2 2 5 . 2 2 7}$ & $\mathbf{0 . 0 0 2 2 1}$ & $\mathbf{2 8 . 4 2 9}$ & $\mathbf{0 . 0 1 9 7 1}$ & $\mathbf{2 5 3 . 6 5 6}$ \\
\hline 18 & Electrical equipment & $\mathbf{0 . 0 0 2 7 6}$ & $\mathbf{3 5 . 5 8 6}$ & 0.00047 & 6.017 & $\mathbf{0 . 0 0 3 2 3}$ & $\mathbf{4 1 . 6 0 3}$ \\
\hline 19 & Machinery and equipment & $\mathbf{0 . 0 0 3 4 7}$ & $\mathbf{4 4 . 6 8 4}$ & 0.00061 & 7.908 & $\mathbf{0 . 0 0 4 0 8}$ & $\mathbf{5 2 . 5 9 2}$ \\
\hline 20 & Motor vehicles and trailers & 0.00167 & 21.434 & $\mathbf{0 . 0 0 1 7 2}$ & $\mathbf{2 2 . 0 8 7}$ & $\mathbf{0 . 0 0 3 3 9}$ & $\mathbf{4 3 . 5 2 1}$ \\
\hline 21 & Other transport equipment & 0.00112 & 14.361 & 0.00021 & 2.686 & 0.00133 & 17.047 \\
\hline
\end{tabular}


Table 7 (cont.). The Effects of China and US's GDP decline on Korea's By-industry GDP (2014, \%, millions of dollars)

\begin{tabular}{|c|l|c|c|c|c|c|c|}
\hline \multicolumn{2}{|l|}{} & \multicolumn{2}{|c|}{$\begin{array}{c}\text { When China's GDP fall } \\
\text { by 1\% }\end{array}$} & \multicolumn{2}{c|}{$\begin{array}{c}\text { When US's GDP fall by } \\
\mathbf{0 . 3 \%}\end{array}$} & \multicolumn{2}{c|}{$\begin{array}{c}\text { G2 } \\
\text { Total effect }\end{array}$} \\
\hline Korea's GDP decrease by & Rate & Value & Rate & Value & \multicolumn{2}{c|}{ Rate } & Value \\
\hline Sector & Total & 0.06605 & 850.177 & 0.01421 & 182.933 & 0.08026 & 1033.110 \\
\hline 22 & Furniture & 0.00070 & 8.999 & 0.00009 & 1.223 & 0.00079 & 10.222 \\
\hline 23 & $\begin{array}{l}\text { Repair and installation of } \\
\text { machinery and equipment }\end{array}$ & - & - & - & - & - & - \\
\hline 24 & Electricity, gas, steam & 0.00128 & 16.465 & 0.00027 & 3.463 & 0.00155 & 19.928 \\
\hline 25 & $\begin{array}{l}\text { Water collection, treatment and } \\
\text { supply }\end{array}$ & 0.00013 & 1.690 & 0.00003 & 0.403 & 0.00016 & 2.093 \\
\hline 26 & Sewerage; waste collection & 0.00031 & 3.954 & 0.00007 & 0.948 & 0.00038 & 4.902 \\
\hline 27 & Construction & 0.00011 & 1.459 & 0.00002 & 0.303 & 0.00013 & 1.762 \\
\hline $28-56$ & Services & 0.02046 & 263.303 & 0.00501 & 64.434 & 0.02547 & 327.737 \\
\hline
\end{tabular}

Source: calculated by the author based on WIOD 2014.

Note: 1) Service is least considered in this paper.

The table above elaborates how China and US's GDP decline would have spillover effect on Korea's GDP by sector. In the scenario of China's GDP down by $1 \%$, in detail, the most affected sector is manufacture of computer, electronic products (-US\$225.2million), followed by chemicals and related products (- US\$ 82.8 million) and machinery and equipment (-US\$ 44.7million) in sequence. Regarding the scenario of US's GDP down by $0.3 \%$, computer and electronic products (-US\$28.4million) has the biggest spillover effect as well. Next come motor vehicles and trailers (-US\$22.1million) and chemicals (-US\$ 13.2million). Putting all together under the scenario of China and US's bilateral GDP reduction from a chain of tariff strikes, the most damaged industry is overwhelmingly computer and electronic manufacture (-US\$ 253.6million). The second most damaged is chemicals (-US\$ 96million), followed by machinery and equipment (- US\$ 52.6million), motor vehicles and trailers (-US\$ 43.5million), and electrical equipment (-US\$ 41.6million) in order.

To sum up, considering the extent that Korea would be damaged from China and US's economic slowdown, the damage from China is larger than the one from US. Even though the study applies the identical GDP reduction by $1 \%$, the damage Korea would suffer from China is still larger.

\section{When China and US's Exports Fall}

Prior to entering into the main analysis, this paper examines elasticity analysis in order to identify China and US's estimated reduced imports due to mutual tariff escalation and then calculates how their exports reduction would have effects on Korea economy. It takes advantage of information regarding tariff growth rate and the imports demand elasticity. The initial stage of the calculation is computing a country's imports reduction with the given information and then transposing it in the other country's exports. So, the calculation of it is presented as follows. (Suppose that a commodity's price tends to absorb $100 \%$ of tariff. For example, if $10 \%$ of tariff is applied on a commodity, the commodity's price consequently increases by $10 \%$.)

Table 8. China and US's Expected Exports after Tariffs Execution

\begin{tabular}{|c|c|}
\hline & Expected exports reduction \\
\hline China & $-25.6 \%$ \\
\hline US & $-21.3 \%$ \\
\hline
\end{tabular}

Therefore, China-US trade war would affect China's estimated import decline by $21.3 \%$ and in other words, US's estimated exports to China would decline by $21.3 \%$. Likewise, US's estimated import, i.e., China's estimated exports to US would be expected down by $25.6 \%$. 
Table 9. Calculation of G2's Expected Imports Reduction

\begin{tabular}{|c|c|c|c|c|}
\hline & $\begin{array}{c}\text { Change of import price } \\
(=\text { import-weighted average tariff rate) }\end{array}$ & $\begin{array}{c}\text { Import demand } \\
\text { elasticity }\end{array}$ & $\begin{array}{c}\text { Tariff-affected imported } \\
\text { goods }\end{array}$ & Estimated imports \\
\hline China & $32.0 \%$ & -0.966 & $68.8 \%$ & $\mathbf{- 2 1 . 3 \%}$ \\
\hline US & $26.6 \%$ & -0.997 & $96.8 \%$ & $\mathbf{- 2 5 . 6 \%}$ \\
\hline
\end{tabular}

Source: calculated by the author based on import demand elasticity from Ghodsi, Grubler, and Strehrer (2016)

Note 1) Import-weighted average tariff rates refer to Figure 5 and 7.

Note 2) China's tariff-affected imported goods (\%) = China's US tariff-affected imports value / China's total imports value from US.

Note 3) Import demand elasticity is identically applied to all countries.

\section{When China's Exports to US Fall}

Table 10. Decomposition of China's Gross Exports to US by Factors of Value Added (2014, billions of dollars)

\begin{tabular}{|c|c|c|c|c|c|}
\hline China's exports to US & DVA & RDA & FVA & PDC & accounting error \\
\hline 347.311 & 277.702 & 1.660 & 55.49 & 5.494 & 6.961 \\
\hline $100.00 \%$ & $79.96 \%$ & $0.48 \%$ & $15.98 \%$ & $1.58 \%$ & $2.00 \%$ \\
\hline
\end{tabular}

Source: calculated by the author based on WIOD 2014.

Note 1) Technically speaking, RDA can be combined as a category, DVA.

Table 11. Decomposition of China's Gross Exports to US by Final Destination (2014, billions of dollars)

\begin{tabular}{|c|c|c|c|c|c|c|}
\hline China's exports to US & China & US & Korea & RoW & PDC & $\begin{array}{c}\text { accounting } \\
\text { error }\end{array}$ \\
\hline 347.311 & 1.660 & 317.178 & 0.354 & 15.569 & 5.494 & 7.054 \\
\hline $100.00 \%$ & $0.48 \%$ & $91.32 \%$ & $0.10 \%$ & $4.48 \%$ & $1.58 \%$ & $2.03 \%$ \\
\hline
\end{tabular}

Source: calculated by the author based on WIOD 2014.

When China exports goods to US, domestic value added absorbed abroad (DVA) is US\$277.7billion comprising about $80 \%$ of all gross exports. Domestic value added going back to China (RDA) is US\$ US\$ 1.6billion accounting for $0.48 \%$ and foreign value added from either US or Korea or rest of the world (FVA) takes up about $16 \%$ of all. When it comes to exports of intermediate goods, it is generated by a final demand country via additional processing and reexporting. Thus, the gross exports can be divided by final demand country. In terms of decomposition of China's exports to US by final destination, understandably, the largest proportion is ultimately consumed in US accounting for $91 \%$. The percentage of its exports to US re-imported and consumed in China amounts to $0.48 \%$. The case of spending final goods in Korea is $0.10 \%$ of all and US\$ 354 milion in dollar.

Table 12. Decomposition of China's Gross Exports to US by Final Destination and Value Added Factors (2014, billions of dollars)

\begin{tabular}{|c|c|c|c|c|c|c|c|c|c|c|}
\hline \multirow{3}{*}{$\begin{array}{l}\text { China' } \\
\text { s } \\
\text { export } \\
\text { s to } \\
\text { US }\end{array}$} & $\begin{array}{c}\text { Final } \\
\text { destinatio }\end{array}$ & \multicolumn{4}{|c|}{ US } & China & Korea & RoW & \multirow{3}{*}{ PDC } & \multirow{3}{*}{$\begin{array}{c}\text { accountin } \\
\mathrm{g} \text { error }\end{array}$} \\
\hline & $\mathrm{Va}$ & DVA & \multicolumn{3}{|c|}{ FVA } & RVD & DVA & DVA & & \\
\hline & $\begin{array}{l}\text { Trade } \\
\text { flow }\end{array}$ & $\begin{array}{c}\mathbf{C H} \rightarrow \mathbf{U} \\
\mathbf{S}\end{array}$ & $\begin{array}{c}\mathrm{US} \rightarrow \mathbf{C H} \rightarrow \mathbf{U} \\
\mathbf{S}\end{array}$ & $\begin{array}{c}\mathrm{KR} \rightarrow \mathbf{C H} \rightarrow \mathbf{U} \\
\mathbf{S}\end{array}$ & $\begin{array}{c}\mathrm{RoW} \rightarrow \mathbf{C H} \rightarrow \mathbf{U} \\
\mathbf{S}\end{array}$ & $\begin{array}{c}\mathbf{C H} \rightarrow \mathbf{U S} \rightarrow \mathrm{C} \\
\mathrm{H}\end{array}$ & $\begin{array}{c}\mathbf{C H} \rightarrow \mathbf{U S} \rightarrow \mathrm{K} \\
\mathrm{R}\end{array}$ & $\begin{array}{c}\mathbf{C H} \rightarrow \mathbf{U S} \rightarrow \text { Ro } \\
\text { W }\end{array}$ & & \\
\hline \multicolumn{2}{|c|}{347.311} & 261.686 & 3.953 & 4.762 & 46.718 & 1.660 & 0.354 & 15.569 & 5.494 & 7.114 \\
\hline \multicolumn{2}{|c|}{$100.00 \%$} & $75.35 \%$ & $1.14 \%$ & $1.37 \%$ & $13.45 \%$ & $0.48 \%$ & $0.10 \%$ & $4.48 \%$ & $\begin{array}{c}1.58 \\
\%\end{array}$ & $2.05 \%$ \\
\hline
\end{tabular}

Source: calculated by the author based on WIOD 2014. 
Taking account of China's exports to US in two perspectives, final destination and value added factors at the same time, it can be depicted in the table above. It illuminates how Korea is associated in the form of forward linkage and backward linkage in China's gross exports to US. In a nutshell, Korea is engaged in production as well as final demand in the process of China's exports to US. A trade between two countries is not merely bilaterally concerned, but there are complicated connections in harness with foreign countries before and after the exports.

First of all, from production's point of view, the case of Korea's intermediate exports to China and re-exports to US as a final destination (Korea $\rightarrow$ China $\rightarrow$ US ) comprise $1.37 \%$ of China's gross exports to US. By assumption, when China's exports to US down by $25.6 \%$ come to the realization, Korea's intermediate exports to China accordingly fall by US\$ 1.219 billion $(-25.6 \%)$ in 'Korea $\rightarrow$ China $\rightarrow$ US' trade.

Secondly, in the light of China's gross exports to US setting Korea as a final destination (China $\rightarrow$ US $\rightarrow$ Korea), when China's exports to US decline by $25.6 \%$, Korea's final demand would be on a par with $25.6 \%$, down by US\$ 90.76million. Its impacts on Korea's exports and GDP by industry are presented as follows.

Table 13. Effects of Decline in China's Exports to US on Korea's Economy by Industry (2014, millions of dollar)

\begin{tabular}{|c|c|c|c|}
\hline \multirow{2}{*}{\multicolumn{2}{|c|}{ When China's exports to US fall by $25.6 \%$}} & \multirow{2}{*}{\begin{tabular}{|c|} 
'Korea $\rightarrow$ China $\rightarrow$ US' \\
$\begin{array}{c}\text { Korea's forward linkage in China's } \\
\text { exports to US }\end{array}$ \\
\end{tabular}} & \multirow{2}{*}{\begin{tabular}{|c|} 
'China $\rightarrow$ US $\rightarrow$ Korea' \\
$\begin{array}{c}\text { Korea's backward linkage in China's } \\
\text { exports to US }\end{array}$ \\
\end{tabular}} \\
\hline & & & \\
\hline & & Value & Value \\
\hline Sector & Total & $-1,219.114$ & -90.759 \\
\hline 1 & Crop and animal production & -0.323 & -0.393 \\
\hline 2 & Forestry and logging & -0.080 & -0.072 \\
\hline 3 & Fishing and aquaculture & -0.014 & -0.064 \\
\hline 4 & Mining and quarrying & -1.471 & -0.448 \\
\hline 5 & Food and beverages & -3.020 & -0.674 \\
\hline 6 & Textiles and apparel & -84.232 & -1.803 \\
\hline 7 & Wood & -2.574 & -0.779 \\
\hline 8 & Paper & -4.576 & -1.747 \\
\hline 9 & Printing and recorded media & -0.259 & -0.041 \\
\hline 10 & Coke and refined petroleum & -1.848 & -0.932 \\
\hline 11 & Chemicals & -32.342 & -13.939 \\
\hline 12 & Pharmaceutical products & -2.547 & -1.252 \\
\hline 13 & Rubber and Plastic & -22.563 & -3.322 \\
\hline 14 & Non-metallic mineral & -6.685 & -1.989 \\
\hline 15 & Basic metals & -8.967 & -4.152 \\
\hline 16 & Fabricated metal products & -21.540 & -6.275 \\
\hline 17 & Computer and electronic & -777.344 & -21.753 \\
\hline 18 & Electrical equipment & -90.100 & -8.859 \\
\hline 19 & Machinery and equipment & -72.793 & -11.591 \\
\hline 20 & Motor vehicles and trailers & -28.949 & -5.207 \\
\hline 21 & Other transport equipment & -8.516 & -0.852 \\
\hline 22 & Furniture & -32.593 & -0.970 \\
\hline 23 & $\begin{array}{l}\text { Repair and installation of machinery and } \\
\text { equipment }\end{array}$ & - & - \\
\hline 24 & Electricity, gas, steam & -0.501 & -0.110 \\
\hline 25 & Water collection, treatment and supply & -0.032 & -0.007 \\
\hline 26 & Sewerage; waste collection & -0.302 & -0.039 \\
\hline 27 & Construction & - & - \\
\hline $28-56$ & Services & -14.945 & -3.487 \\
\hline
\end{tabular}

Source: calculated by the author based on WIOD 2014.

Note 1) Service is least considered in this paper.

In forward linkage perspective, the most damaged industry is viewed as computer and electronic (US\$ 777.3 million) followed by electrical equipment (US\$ 90.1million), textile and apparel (US\$ 84.2million), and machinery (US\$ 72.8 million). What matters is that Korea generally has large proportion of intermediate goods 
exports in terms of its bilateral trade with China. On the whole, its effect on Korea's gross intermediate exports to China would be expected down by $1.05 \%$ and comprehensively, Korea's gross exports to China would decrease by $0.72 \%$.

From backward linkage aspect, the most affected sectors by decrease in China's exports to US are computer and electronic (US\$21.8million), chemicals (US\$ 14million), and machinery (US\$ 11.6million) in order. Thus, Korea's decrease in final demand from China is equal to US\$ 90.8million. Given Korea's GDP, Korea would suffer from $-0.007 \%$ of GDP growth.

\section{When US's Exports to China Fall}

Table 14. Decomposition of US's Gross Exports to China by Factors of Value Added (2014, billions of dollars)

\begin{tabular}{|c|c|c|c|c|c|}
\hline US's exports to China & DVA & RDA & FVA & PDC & accounting error \\
\hline 112.051 & 92.547 & 2.376 & 13.577 & 2.290 & 1.261 \\
\hline $100.00 \%$ & $82.59 \%$ & $2.12 \%$ & $12.12 \%$ & $2.04 \%$ & $1.13 \%$ \\
\hline
\end{tabular}

Source: calculated by the author based on WIOD 2014.

Table 15. Decomposition of US's Gross Exports to China by Final Destination (2014, billions of dollars)

\begin{tabular}{|c|c|c|c|c|c|c|}
\hline US's exports to China & China & US & Korea & RoW & PDC & $\begin{array}{c}\text { accounting } \\
\text { error }\end{array}$ \\
\hline 112.051 & 95.228 & 2.376 & 0.382 & 10.422 & 2.290 & 1.354 \\
\hline $100.00 \%$ & $84.99 \%$ & $2.12 \%$ & $0.34 \%$ & $9.30 \%$ & $2.04 \%$ & $1.21 \%$ \\
\hline
\end{tabular}

Source: calculated by the author based on WIOD 2014.

In 2014, US's gross exports to China is US\$ 112.1 billion in total. US's domestic value added accounts for $82.6 \%$, US\$ 92.5billion of value added, and domestic value added returned home takes up $2.12 \%$ of all, US\$ 2.4 billion in value. Foreign value added from other countries $12.12 \%$, US\$ 13.6 billion in value. Looking at US's gross exports to China on the basis of final demand country, $85 \%$ of the gross exports was satisfied in China for the consumption of final goods. $2.12 \%$ of US's gross exports to China returns US and is used in home country. Meanwhile, $0.34 \%$ of all is finally consumed in Korea.

Table 16. Decomposition of US's Gross Exports to China by Final Destination and Value Added Factors (2014, billions of dollars)

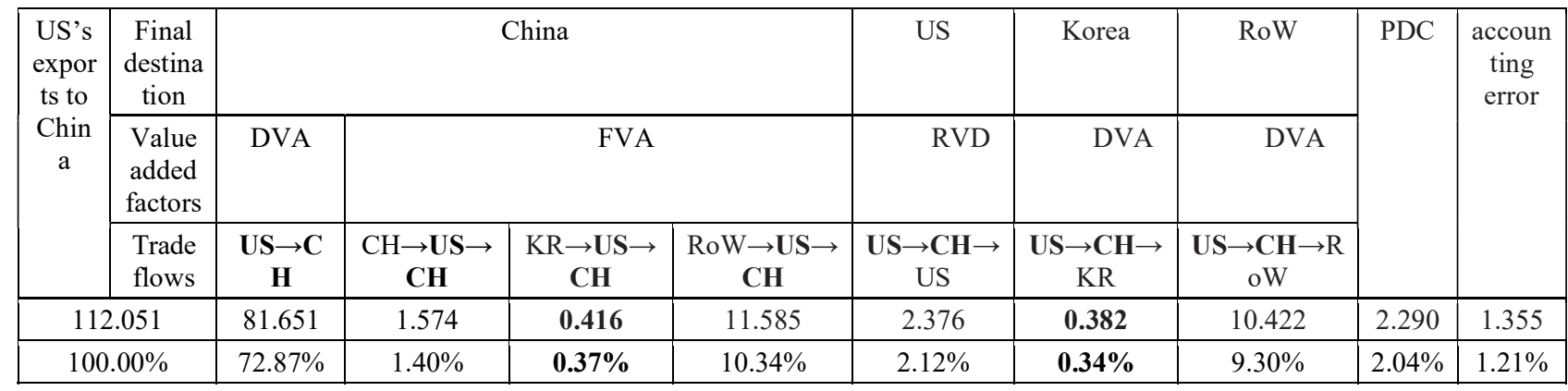

Source: calculated by the author based on WIOD 2014.

Considering two aspects simultaneously, Korea is in harness with US's gross exports to China in the ways of forward linkage and backward linkage. In terms of output, Korea's intermediate exports to US, which re-exports them to China through additional refinement and polishing of goods and the goods are completed and used in China (Korea $\rightarrow$ US $\rightarrow$ China). Korea taking part in forward linkage of US's gross exports to China occupies $0.37 \%$ of the whole, which is US\$ 416million in dollar. As mentioned earlier, given the scenario where US's exports to China decrease by $21.3 \%$, Korea's exports of intermediate goods to US would accordingly confront reduction by US\$ 88.5million. 
With respect to backward linkage, on the contrary, US exports intermediate goods to China, which re-exports reprocessed goods (either intermediate or final goods) to Korea and they are consequently spent in Korea. Regarding 'US $\rightarrow$ China $\rightarrow$ Korea' trade, $0.34 \%$ of US's gross exports to China is consumed in Korea. If $21.3 \%$ decrease in US's exports to China come to surface, Korea's final demand would experience the decline by US\$ 81.3million. The detailed by-industry impacts on Korea are presented in the following table.

Table 17. Effects of Decline in US's Exports to China on Korea's Economy by Industry (2014, millions of dollars)

\begin{tabular}{|c|c|c|c|}
\hline \multirow{2}{*}{\multicolumn{2}{|c|}{ When US's exports to China fall by $21.3 \%$}} & \multirow{3}{*}{$\begin{array}{c}\text { 'Korea } \rightarrow \text { US } \rightarrow \text { China' } \\
\text { Korea's forward linkage } \\
\text { in US's exports to China } \\
\text { Value } \\
\end{array}$} & \multirow{3}{*}{$\begin{array}{c}\text { 'US } \rightarrow \text { China } \rightarrow \text { Korea' } \\
\begin{array}{c}\text { Korea's backward linkag } \\
\text { in US's exports to China }\end{array} \\
\text { Value } \\
\end{array}$} \\
\hline & & & \\
\hline & & & \\
\hline Sector & Total & -88.534 & -81.306 \\
\hline 1 & Crop and animal production & -3.478 & -11.169 \\
\hline 2 & Forestry and logging & -0.053 & -0.334 \\
\hline 3 & Fishing and aquaculture & -0.019 & -0.0002 \\
\hline 4 & Mining and quarrying & -0.424 & -3.149 \\
\hline 5 & Food and beverages & -2.486 & -2.883 \\
\hline 6 & Textiles and apparel & -0.454 & -0.583 \\
\hline 7 & Wood & -0.435 & -0.805 \\
\hline 8 & Paper & -1.346 & -2.285 \\
\hline 9 & Printing and recorded media & -0.113 & -0.150 \\
\hline 10 & Coke and refined petroleum & -0.459 & -1.559 \\
\hline 11 & Chemicals & -5.473 & -12.766 \\
\hline 12 & Pharmaceutical products & -1.199 & -0.250 \\
\hline 13 & Rubber and Plastic & -1.225 & -1.045 \\
\hline 14 & Non-metallic mineral & -0.336 & -0.359 \\
\hline 15 & Basic metals & -1.019 & -1.398 \\
\hline 16 & Fabricated metal products & -1.127 & -0.871 \\
\hline 17 & Computer and electronic & -7.619 & -9.324 \\
\hline 18 & Electrical equipment & -1.785 & -1.425 \\
\hline 19 & Machinery and equipment & -11.134 & -4.670 \\
\hline 20 & Motor vehicles and trailers & -19.507 & -0.601 \\
\hline 21 & Other transport equipment & -17.922 & -0.812 \\
\hline 22 & Furniture & -2.500 & -1.377 \\
\hline 23 & $\begin{array}{c}\text { Repair and installation of machinery and } \\
\text { equipment }\end{array}$ & -0.0001 & -0.0001 \\
\hline 24 & Electricity, gas, steam & -0.003 & -0.020 \\
\hline 25 & Water collection, treatment and supply & -0.00003 & -0.0001 \\
\hline 26 & Sewerage; waste collection & -0.189 & -0.451 \\
\hline 27 & Construction & -0.0003 & -0.0004 \\
\hline $28-56$ & Services & -8.229 & -23.022 \\
\hline
\end{tabular}

Source: calculated by the author based on WIOD 2014.

Note: 1) Service is least considered in this paper. Refer to Appendix A to see the details.

In forward linkage perspective, the most affected sector from the decrease in US's exports to China is motor vehicle (US\$ 19.5million). Next comes transports equipment (US\$ 17.9million), followed by machinery (US\$ 11.1million). The table demonstrates that those industries are deeply associated with intermediate output to US. The total value of reduction is US\$ 88.5million from US's exports to China down by $21.3 \%$. As a result, Korea's gross intermediate goods to US would undergo down by $0.2 \%$, and it would be down by $0.11 \%$ in terms of Korea's gross exports to US.

In backward linkage perspective, chemicals (US\$ 12.8million), crop and animal production (US\$ 11.2million), computer and electronics (US\$ 9.3million) are regarded as the most damaged sectors in terms of final demand. As Korea's final demand in 'US $\rightarrow$ China $\rightarrow$ Korea' trade would fall by US\$81.3million, Korea would suffer from $0.0063 \%$ of GDP growth. 


\section{Conclusion from the Findings}

The studies on China-US's trade war and its impacts on Korean economy were implemented in the consideration of two hypotheses; China and US's economic slowdown (GDP), and their bilateral exports decline. Making a comparison of the results from the two models, the ripple effects that Korea would suffer from are bigger in China's case. Even though it is under the same condition where China and US's GDP identically fall by 1\%, China's case would bring about stronger impacts on Korea. In a nutshell, the outcome illustrates that the extent of the damage that Korea would undergo is always larger in China's bad-case scenarios compared to US's bad-case scenarios which reveals that Korea is more associated with China than US in global value chains. The findings of the analysis are arranged and diagrammed in a table as follows.

There are some limitations in this study. First of all, the paper used data released in 2016 which practically underlies input output data in 2014. The data used in this paper is hard to perfectly fit into a current situation of Chins-US trade war still happening in 2019. So, there is a concern over applying the analysis findings to practice in reality. Also, in the middle of 'decomposition of gross exports' analysis, there existed a certain amount of accounting errors. It is a shame that the study failed to completely decompose gross exports into 16 value added terms even though the error is small and does not have a significant influence on the results. Thus, the results have a margin of error to some degree.

Table 18. The Findings of Analysis on China-US Trade War's Impacts on Korea

\begin{tabular}{|c|c|c|c|c|}
\hline & & \multicolumn{3}{|c|}{ Korea's GDP } \\
\hline \multirow[t]{2}{*}{$(1)$} & China's GDP fall by $1 \%$ & \multicolumn{3}{|c|}{$-0.066 \%$} \\
\hline & US's GDP fall by $0.3 \%$ & \multicolumn{3}{|c|}{$-0.014 \%$} \\
\hline \multirow[t]{4}{*}{ (2) } & \multirow[t]{2}{*}{ China's exports to US fall by $25.6 \%$} & $\begin{array}{l}\text { Korea's gross intermediate } \\
\text { exports to China }\end{array}$ & $\begin{array}{l}\text { Korea's gross exports to } \\
\text { China }\end{array}$ & Korea's GDP \\
\hline & & $-1.05 \%$ & $-0.72 \%$ & $-0.007 \%$ \\
\hline & \multirow[t]{2}{*}{ US's exports to China fall by $21.3 \%$} & $\begin{array}{c}\text { Korea's gross intermediate } \\
\text { exports to US }\end{array}$ & Korea's gross exports to US & Korea's GDP \\
\hline & & $-0.2 \%$ & $-0.11 \%$ & $-0.0063 \%$ \\
\hline
\end{tabular}

Source: rearranged by the author based on the findings in the text.

\section{References}

1. Bank of Korea (2014). Input Output Analysis (2014). Available at: http://www.bok.or.kr/portal/ bbs/ P0000606/view.do?nttId=206134\&menuNo=200612

2. Bank of Korea (2016). Decomposition of Korea's exports to China and US Protectionism's effects on Korean Economy. Available at:

http://www.bok.or.kr/portal/bbs/P0000559/view.do?nttId=224205\&menuNo=200690

3. Bank of Korea (2017). Understanding of World Input Output Tables(WIOT). Quarterly National Accounts Review, 3, 46-70. Available at: https://unstats.un.org/unsd/nationalaccount/docs/SUT_IOT_HB Final_Cover.pdf.

4. Behravesh, Nariman., Johnson, Sara L., Anton John (2018). Impact of a Global Trade War on the Economy. IHS Markit. Available at: https://ihsmarkit.com/solutions/us-china-trade-war-impacts.html (accessed October 11, 2019).

5. Bown, Chad P., Jung, Euijin. And Zhang, Yiwen. 2019. "Trump Has Gotten China to Lower Its Tariffs. Just Toward Everyone Else". Peterson Institution for International Economics. September 20. https://www.piie.com/blogs/trade-and-investment-policy-watch/us-china-trade-war-guns-august

6. Caceres, Carlos, Cerdeiro, Diego A., Mano, Rui C. (2019). Trade Wars and Trade Deals: Estimated Effects using a Multi-Sector Model. IMF Working Paper-19/134. Available at: https://ideas.repec.org/f/c/pca348.html.

7. Daudin, Guillaume, Rifart, Christine, Schweisguth, Danielle (2011). Who Produces for Whom in the World Economy? Canadian Journal of Economics, 44(4), 1403-1437. https://doi.org/10.1111/j.15405982.2011.01679.x. 
8. Hummels, David, Ishii, Jun, Yi, Kei-Mu (2001). The nature and growth of vertical specialization in world trade, Journal of International Economics, 54, 75-96. Available at: https://ideas.repec.org/a/eee/inecon/v54y2001i1p75-96.html.

9. Johnson, Robert C., Noguera, Guillermo (2012). Accounting for intermediates: Production sharing and trade in value added. Journal of International Economics, 86, 224-236. DOI: 10.1016/j.jinteco.2011.10.003.

10. Kang, Naeyoung, Kim, Gunwoo (2018). Changes in Global Specialization Structure and Implications. KITA IIT Trade Focus, 53(December). Available at: https://www.kita.net/.

11. Kim, Hankwon (2019). Prospects of China-US Strategic Competition and Implications for Korea. IFANS. 22. Paper presented at the weekly meeting of Korea National Diplomatic Academy, Seoul, Korea. Available at: https://www.kita.net/

12. Kim, Seogmin, Kim, Eunyoo (2009). Trade Conflict between China and the United States and its Impact on Korean Economy. Industrial Economic Research, 31(6), 2263-2291. Available at: https://www.kita.net/

13. Koopman, Robert, Wang, Zhi, Wei, Jinshang (2014). Tracing Value-Added and Double Counting in Gross Exports. American Economic Review, 104(2), 459-494. DOI: 10.1257/aer.104.2.459.

14. Kumagai, Satoru, Gokan, Toshitaka, Ysubota, Kenmei, Isono, Ikumo, Hayakawa, Kazunobu (2019). Economic Impacts of the US-China Trade War on the Asian Economy: An Applied Analysis of IDEGSM. IDE Discussion Paper 760. Available at: http://hdl.handle.net/2344/00050856.

15. Lee, Wooki, Lee, Yinkyu, Hong, Youngeun (2013). Analysis on Korea's Global Value Chain Using World Input Output Tables. Bank of Korea Issue Paper Series 2013-4. Available at: https://www.bok.or.kr/imerEng/bbs/B0000268/view.do?nttId=187995\&menuNo=600354\&pageIndex=21

16. Moon, Byeonggi, Jung, Guiil (2018). How US's trade measures on China would affect Korea's exports. KITA IIT Trade Brief, 7, 1-8. Available at: https://www.kita.net/.

17. Moon, Byeonggi, Kang, Seongeun, Yoo, Seokyung (2019). U.S.-China Trade Disputes' Impacts on Exports. KITA IIT Trade Focus. 24 (June). Available at: https://www.kita.net/.

18. Nam, Hyuggi (2018). U.S.-China trade war \& Strategies for Korean Firms. Master Diss. Catholic Kwan Dong University. Available at: http://www.cku.ac.kr/.

19. Seo, Changbae (2017). A Study Case on China's WTO Trade Conflicts. Chinese Law Review, 29, 423451. Available at: https://www.tandfonline.com/toc/rclr20/current.

20. Wang, Yunjong (2019). U.S.-China Trade Conflict and its Impact on Northeast Asia's Trading Order. Economic Research in North-Eastern Asia, 31(4), 1-40. Available at: https://www.nber.org/papers/w26353.

21. Waugh, Michael E. (2019). The Consumption response to Trade Shocks: Evidence from the US-China Trade War. NBER Working Paper 26353. Available at: https://www.cato.org/publications/research-briefseconomic-policy/consumption-response-trade-shocks-evidence-us-china.

22. York, Erica, Pomerleau, Kyle, Eastman, Scott (2019). Tracking the Economic Impact of U.S. Tariffs and Retaliatory Actions, Tax Foundation. May 31. https://taxfoundation.org/tariffs-trump-trade-war (accessed October 14, 2019). 